\title{
Extravillous trophoblast cells-derived exosomes promote vascular smooth muscle cell migration
}

\section{Carlos Salomon ${ }^{1,2 *}$, Sarah Yee ${ }^{1}$, Katherin Scholz-Romero ${ }^{1}$, Miharu Kobayashi ${ }^{1}$, Kanchan Vaswani ${ }^{1}$, David Kvaskoff' ${ }^{1}$, Sebastian E. Illanes ${ }^{1,2}$, Murray D. Mitchell ${ }^{1}$ and Gregory E. Rice ${ }^{1,2}$}

1 Centre for Clinical Diagnostics, Royal Brisbane and Women's Hospital, University of Queensland Centre for Clinical Research, Brisbane, QLD, Australia

2 Department of Obstetric and Gynaecology, Faculty of Medicine, Universidad de los Andes, Santiago, Chile

\section{Edited by:}

Carlos Alonso Escudero,

Universidad del Bio Bio, Chile

\section{Reviewed by:}

Siu-Lung Chan, University of

Vermont, USA

Carlos Alonso Escudero,

Universidad del Bio Bio, Chile

Motohiro Komaki, Tokyo Medical

and Dental University Graduate

School, Japan

\section{*Correspondence}

Carlos Salomon, Faculty of Health Sciences, Royal Brisbane Hospital, University of Queensland Centre for Clinical Research, University of Queensland, Building 71/918,

Herston, Brisbane, QLD 4029,

Australia

e-mail:c.salomongallo@uq.edu.au Web: www.uqccr.uq.edu.au/
Background: Vascular smooth muscle cells (VSMCs) migration is a critical process during human uterine spiral artery (SpA) remodeling and a successful pregnancy. Extravillous trophoblast cells (EVT) interact with VSMC and enhance their migration, however, the mechanisms by which EVT remodel SpA remain to be fully elucidated. We hypothesize that exosomes released from EVT promote VSMC migration.

Methods: JEG-3 and HTR-8/SVneo cell lines were used as models for EVT. Cells were cultured at $37^{\circ} \mathrm{C}$ and humidified under an atmosphere of $5 \% \quad \mathrm{CO}_{2}$-balanced $\mathrm{N}_{2}$ to obtain $8 \% \mathrm{O}_{2}$. Cell-conditioned media were collected, and exosomes (exo-JEG-3 and exo- HTR-8/SVneo) isolated by differential and buoyant density centrifugation. The effects of exo-EVT on VSMC migration were established using a real-time, live-cell imaging system (Incucyte ${ }^{\mathrm{TM}}$ ). Exosomal proteins where identified by mass spectrometry and submitted to bioinformatic pathway analysis (Ingenuity software).

Results: HTR-8/SVneo cells were significantly more ( $30 \%)$ invasive than JEG-3 cells. HTR-8/SVneo cells released 2.6-fold more exosomes $\left(6.39 \times 10^{8} \pm 2.5 \times 10^{8}\right.$ particles/106 cells) compared to JEG-3 $\left(2.86 \times 10^{8} \pm 0.78 \times 10^{8}\right.$ particles $/ 10^{6}$ cells $)$. VSMC migration was significantly increased in the presence of exo-JEG-3 and exo-HTR-8/SVneo compared to control (-exosomes) $(21.83 \pm 0.49 \mathrm{~h}$ and $15.57 \pm 0.32$, respectively, vs. control $25.09 \pm 0.58 \mathrm{~h}, p<0.05)$. Sonication completely abolished the effect of exosomes on VSMC migration. Finally, mass spectrometry analysis identified unique exosomal proteins for each EVT cell line-derived exosomes.

Conclusion: The data obtained in this study are consistent with the hypothesis that the release, content, and bioactivity of exosomes derived from EVT-like cell lines is cell origin-dependent and differentially regulates VSMC migration. Thus, an EVT exosomal signaling pathway may contribute to SpA remodeling by promoting the migration of VSMC out of the vessel walls.

Keywords: exosomes, cell migration, placenta, pregnancy, proteomics

\section{INTRODUCTION}

Remodeling of the uterine spiral arteries (SpA) into low resistance, high capacity vessel begins as extravillous trophoblasts (EVT) invade the decidua during first trimester and is essential for successful pregnancy (Kam et al., 1999). When EVT "plugs" are lost during early second trimester, maternal blood flows through the modified vessels to deliver nutrients and oxygen to support fetal growth and development (Pijnenborg et al., 2006a). EVT continue to invade into the myometrium and remodel the SpA until mid-second trimester (Hamilton and Boyd, 1970; Pijnenborg et al., 1983; Blackburn et al., 2003; American Diabetes Association, 2012). The initial steps of uterine spiral artery remodeling consists of vessel dilatation, vascular smooth muscle cells (VSMC) separation, endothelial cell swelling, EVT infiltration, and fibrinoid deposition (Pijnenborg et al., 2006b). VSMC migrate or undergo apoptosis and are replaced by fibriniod material, in which EVT cells embed. Recently Bulmer et al. showed that during SpA remodeling, VSMC migrate outside of the artery, and this phenomenon is enhanced in the presence of EVT (Bulmer et al., 2012). While the mechanisms by which EVTs remodel SpA remain to be fully elucidated, available data are consistent with the hypothesis that EVT directly interact with VSMC of the uterine spiral arteries. We propose that the releases of nanoparticles (i.e., exosomes) that contain specific effector molecules (e.g., proteins and miRNAs) are released from EVT and affect the loss of VSMC.

Exosomes $(30-100 \mathrm{~nm})$ are nanovesicles released when late endosomes fuse with the cell membrane (Thery, 2011; Salomon et al., 2013a). Exosomes interact with target cells via multiple pathways including: by directly activating target cell membrane receptors; by modifying the extracellular milieu of the target cell; and by fusing with the cell membrane and releasing the molecular 
cargo into the target cell (Pegtel et al., 2010). Their molecular cargo is: cell-specific (Kobayashi et al., 2014); regulated by tissue physiology and cellular function; and fundamental to their bioactivity.

Exosomes are identified in cell-conditioned media and body fluids indicate that they can be released from different types of cells (Vlassov et al., 2012). Recently, the role of exosomes isolated from placental cells (Salomon et al., 2013a,b) and other cell types (Chen et al., 2014; Lee et al., 2014; Yoon et al., 2014) on cell migration has been established. Exosomes released from first trimester placental mesenchymal stem cells (pMSC) increase endothelial cell migration and vascular tube formation in vitro (Salomon et al., 2013a). Similarly, cytotrophoblastderived exosomes increase EVT migration in vitro (Salomon et al., 2013b).

Consistent with the proposal that exosomal signaling regulates cell migration and invasion, proteins associated with actin cytoskeleton, growth hormone, and VEGF signaling have been identified within exosomes. The effect of EVT-derived exosomes on VSMC migration, however, remains to be established. We, therefore, hypothesize that exosomes released by EVT act paracellularly to promote VSMC migration and thus contributing to SpA remodeling. The aims of this study were: (1) to compare the exosome release and exosomal protein composition derived from EVT cell lines from different origin (JEG-3 and HTR-8/SVneo); and (2) to establish the effect of exosomes from both JEG-3 and HTR-8/SVneo cells on human VSMC migration.

Numerous human trophoblastic cell lines have been established, which basically originated from normal tissues or from pathological tissues. JEG3 is a choriocarcinoma cell line cloned from primary choriocarcinoma (Kohler and Bridson, 1971), and HTR8/SVneo is a transformed extravillous trophoblast cell line established by immortalizing primary EVT cells via transfection with simian virus 40 large $\mathrm{T}$ antigen (SV40) (Graham et al., 1993); both cell lines are frequently used as models of physiologically invasive extravillous trophoblast. EVT invasion into the myometrium is a critical process for remodeling the uterine spiral artery (in this stage EVT interact with VSMC), however, the invasiveness capacity between these two cells lines are different. HTR-8/SVneo have significantly higher invasion capacity than JEG-3 (Suman and Gupta, 2012). Moreover, differences between these two cells lines are not just in the invasion capacity, but also in their miRNA profiles (Morales-Prieto et al., 2012) as well as their protease (e.g., metalloproteases-9) expressions (Suman and Gupta, 2012), however, functional differences between exosome vesicles derived from JEG-3 and HTR-8/SVneo remain to be established. Previously, these cells lines have been validated and used routinely as models of EVT function (Suman and Gupta, 2012; Weber et al., 2013).

The aim of this study was to test the hypotheses that: (1) exosomes from EVT act paracellularly to promote VSMC migration; and (2) The release, protein content and bioactivity of exosomes is cell origin-dependent (i.e., EVT cell lines from choriocarcinoma and chorionic villi). The effects of exosomes isolated from the EVT-like cell lines, JEG-3 and HTR-8/SVneo cells on VSMC migration were assessed.

The data obtained are consistent with the hypothesis that the function of EVT-derived exosomes is cell origin specific and showed differences in the release, content and effects on VSMC migration. EVT may communicate with VSMC during SpA remodeling, stimulating their migration through these specific nanovesicles (i.e., exosomes).

\section{MATERIALS AND METHODS MATERIALS}

Medium RPMI 1640, Medium 231, Smooth Muscle Growth Supplement (SMGS), glutamine, antibiotics, HEPES, and phosphate buffered saline (PBS) were obtained from Life Technologies Corporation (Mulgrave, Victoria, Australia). CD63 ELISA kits were obtained from SBI (ExoELISA ${ }^{\mathrm{TM}}$, System Biosciences, Mountain View, CA).

\section{CELL CULTURE}

All experimental procedures were conducted within an ISO17025 accredited (National Association of Testing Authorities, Australia) research facility. All data were recorded within a 21 Code of Federal Regulation (CFR) part 11 compliant electronic laboratory notebook (Irisnote, Redwood City, CA, USA). JEG-3 human choriocarcinoma cell line was purchased from the European Collection of Cell Cultures (Porton Down, Salisbury, UK). The HTR-8/SVneo cell line was kindly donated by Dr. Charles $\mathrm{H}$. Graham (Queen's University, Ontario, Canada). HTR-8/SVneo was established by the transfection of trophoblast cells isolated from first trimester villous explants, with a gene encoding simian virus 40 large $\mathrm{T}$ antigen to immortalize them (Graham et al., 1993). JEG-3 and HTR-8/SVneo cells were maintained in phenol red-free RPMI 1640 medium supplemented with 10\% heatinactivated fetal bovine serum, $1 \%$ non-essential amino acids, $1 \mathrm{mM}$ sodium pyruvate and $100 \mathrm{U} / \mathrm{mL}$ penicillin, and $100 \mathrm{mg} / \mathrm{mL}$ streptomycin. Cultures were maintained at $37^{\circ} \mathrm{C}$ and humidified under an atmosphere of $5 \% \mathrm{CO}_{2}$-balanced $\mathrm{N}_{2}$ to obtain $8 \% \mathrm{O}_{2}$ $\left(\mathrm{pO}_{2} \sim 54 \mathrm{mmHg}\right)$ in an automated PROOX 110-scaled hypoxia chamber (BioSphericsacona, NY, USA). Cells were subcultured with dissociation media, TrypLE ${ }^{\mathrm{TM}}$ Express (Life technologies, USA) and cellular viability was determined by Trypan Blue exclusion and Countess ${ }^{\circledR}$ Automated cell counter (Life Technologies, USA).

Human Vascular Smooth Muscle cells (hVSMC) were purchased from LONZA (Lonza Group Ltd.). VSMC were cultured in 231 media (Life Technologies Corporation) supplemented with SMGS, $100 \mathrm{U} / \mathrm{ml}$ penicillin, and $100 \mu \mathrm{g} / \mathrm{ml}$ streptomycin, at $37^{\circ} \mathrm{C}$ and humidified under an atmosphere of $5 \% \mathrm{CO}_{2}$ balanced $\mathrm{N}_{2}$ to obtain $8 \% \mathrm{O}_{2}\left(\mathrm{pO}_{2} \sim 54 \mathrm{mmHg}\right)$ in an automated PROOX 110-scaled hypoxia chamber (BioSpherics ${ }^{\mathrm{TM}}$, Lacona, NY, USA).

The in vitro cell migration rates of JEG-3 and HTR-8/SVneo we established using real-time cell imaging system (IncuCyte ${ }^{\mathrm{TM}}$ live-cell ESSEN BioScience Inc., Ann Arbor, MI, USA). Using a scratch assay format, cell were imaged every $3 \mathrm{~h}$ to monitor cell migration as previously described (Salomon et al., 2013b).

\section{EXOSOME ISOLATION}

Exosomes were isolated from cell-free JEG-3 and HTR-8/SVneoconditioned media as previously described (Salomon et al., 2013a; Kobayashi et al., 2014). In brief, cell-conditioned media was 
centrifuged at $300 \times \mathrm{g}$ for $15 \mathrm{~min}, 2000 \times \mathrm{g}$ for $30 \mathrm{~min}$, and $12,000 \times \mathrm{g}$ for $45 \mathrm{~min}$ to remove whole cells and debris. The resultant supernatant were passed through a $0.22 \mu \mathrm{m}$ filter sterilize Steritop $^{\mathrm{TM}}$ (Millipore, Billerica, MA, USA) and then centrifuged at $120,000 \times \mathrm{g}$ for $70 \mathrm{~min}$ (Thermo Fisher Scientific Ins., Asheville, NC, USA, Sorvall, SureSpin ${ }^{\mathrm{TM}}$ 630/36, fixed angle rotor). The pellet was resuspended in PBS, washed and recentrifuged $(120,000 \times \mathrm{g}, 75 \mathrm{~min})$. The pellet was resuspended in PBS, layered on a cushion of $30 \%(\mathrm{w} / \mathrm{v})$ sucrose and centrifuged at $110,000 \mathrm{~g}$ for $75 \mathrm{~min}$. The fraction containing exosomes [ $\sim 3.5 \mathrm{ml}, 1.127$ density using OPTi digital refractometer (Bellingham ${ }^{+}$Stanley Inc., Lawrenceville, GA, USA)] was recovered using a Pulse-Free Flow Peristaltic Pump with a flow rate range of $1 \mathrm{ml}$ per min (GILSON Miniplus ${ }^{\circledR}$ model 3) and Fraction Collector (GILSON FC 203B model) and diluted in PBS, and then ultracentrifuged at $110,000 \times \mathrm{g}$ of $70 \mathrm{~min}$. Recovered exosomes were resuspended in $50 \mu \mathrm{l}$ PBS and their protein contents were determined using the Bradford assay (Bio-Rad DC). Exosome samples $(5 \mu \mathrm{l})$ were prepared by adding RIPA buffer $(50 \mathrm{mM}$ Tris, $1 \%$ Triton $\times 100,0.1 \%$ SDS, $0.5 \%$ DOC, $1 \mathrm{mM}$ EDTA, $150 \mathrm{mM}$ $\mathrm{NaCl}$, protease inhibitor) directly to exosomes suspended in PBS and sonicated at $37^{\circ} \mathrm{C}$ for $15 \mathrm{~s}$ three times to disrupt exosomes and solubilise the proteins. Bovine serum albumin (BSA) diluted in RIPA buffer and PBS mixture (1:1) were prepared as protein standards $(0,200,400,600,800,1000,1500 \mu \mathrm{g} / \mathrm{mL})$. Standards and samples (exosomes) were transferred to 96-well plates and procedures outlined by the manufacture were followed. In brief, alkaline copper tartrate solution (Bio-Rab Laboratories, Hercules, CA, USA) and dilute Folin Reagent (Bio-Rab Laboratories,) were added to the samples and incubated for $15 \mathrm{~min}$. The absorbance was read at $750 \mathrm{~nm}$ with Paradigm Detection Platform (Beckman Coulter, USA).

\section{NANOPARTICLE TRACKING ANALYSIS (NTA)}

NTA measurements were performed using a NanoSight NS500 instrument (NanoSight NTA 2.3 Nanoparticle Tracking and Analysis Release Version Build 0033) following the manufacturer's instructions. The NanoSight NS500 instrument measured the rate of Brownian motion of nanoparticles and consists in a light scattering system that provides a reproducible platform for specific and general nanoparticle characterization (NanoSight Ltd., Amesbury, UK). Samples were processed in duplicate and diluted with PBS over a range of concentration to obtain between 10 and 100 particles per image (optimal $\sim 50$ particles $\times$ image) before the analysis with the NTA system. The samples were mixed before introducting into the chamber (temperature: $25^{\circ} \mathrm{C}$ and viscosity: $0.89 \mathrm{cP}$ ) and the camera level set to obtain an image that had sufficient contrast to clearly identify particles while minimizing background noise with video recording (camera level: 10 and capture duration: $60 \mathrm{~s}$ ). Afterwards, the capture videos ( 2 videos per sample) were processed and analyzed. A combination of high shutter speed (450) and gain (250) followed by manual focusing enables optimum visualization of the maximum number of vesicles. A minimum of 200 completed tracks per video were collected in duplicate for each sample analyzed. NTA post acquisition settings were optimized and kept constant between samples (Frames Processed: 1496 of 1496, Frames per

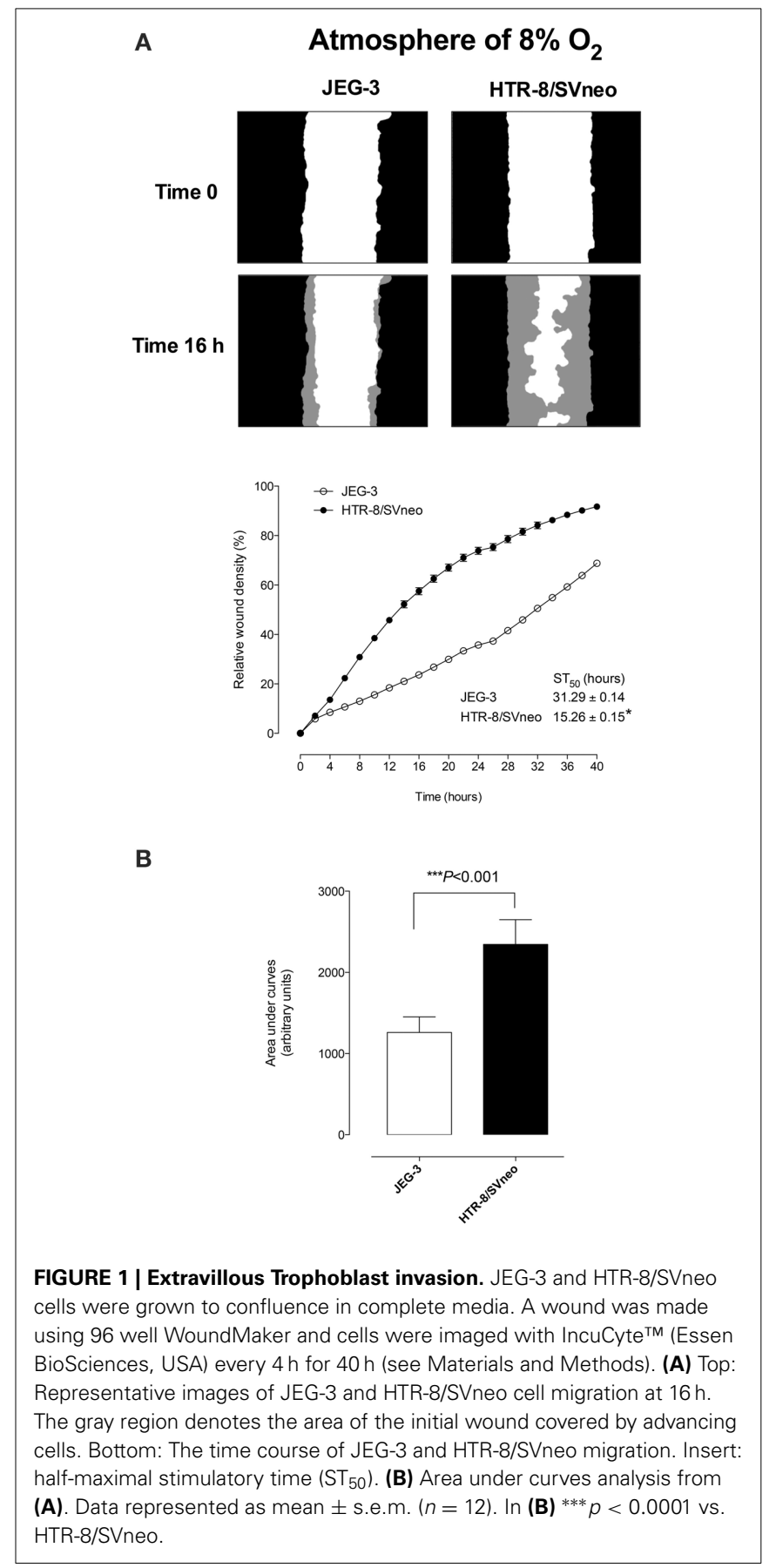

Second: 30, camera shutter: $20 \mathrm{~ms}$; Calibration: $139 \mathrm{~nm} /$ pixel, Blur: $3 \times 3$; Detection Threshold: 10; Min Track Length: Auto; Min Expected Size: Auto), and each video was then analyzed to give the mean, mode, and median particle size together with an estimated number of particles. An Excel spreadsheet (Microsoft Corp., Redmond, Washington) was also automatically generated, recording the concentration at each particle size.

\section{TRANSMISSION ELECTRON MICROSCOPY}

Exosome pellets (as described above, $30 \mu \mathrm{g}$ protein) were fixed in $3 \%(\mathrm{w} / \mathrm{v})$ glutaraldehyde and $2 \%$ paraformaldehyde in cacodylate 

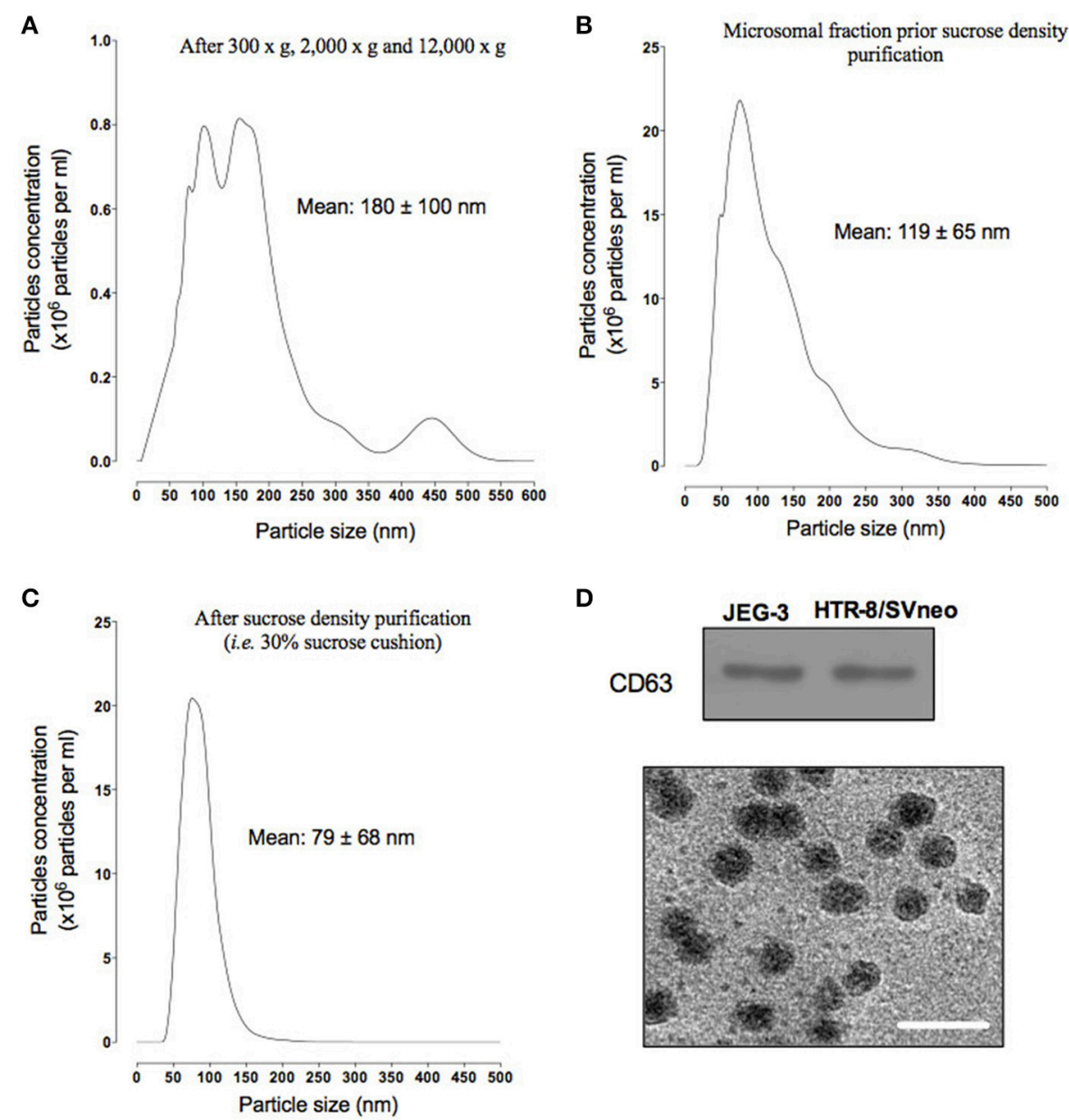

FIGURE 2 | Characterization of exosome from EVT cells. Exosomes were isolated from JEG-3 and HTR-8/SV cells by differential and buoyant density centrifugation (see Materials and Methods). (A-D) shown representative particles size distribution of exosomes isolation steps from JEG-3 and HTR-8/SV cells. (A) After differential

buffer, $\mathrm{pH}$ 7.3. Exosome samples were then applied to a continuous carbon grid and negatively stained with $2 \%$ uranyl acetate. The samples were examined in an FEI Tecnai 12 transmission electron microscope (FEI ${ }^{\mathrm{TM}}$, Hillsboro, OR, USA).

\section{QUANTIFICATION OF CELL-DERIVED EXOSOME}

The concentration of exosomes from EVT cells lines (JEG3 and HTR-8/SVneo) in maternal circulation was expressed as total immunoreactive exosomal CD63 (ExoELISA $^{\mathrm{TM}}$, System Biosciences, Mountain View, CA). Briefly, $10 \mu \mathrm{g}$ of exosomal protein was immobilized in micro-titer plate wells and incubated overnight (binding step). Plates were washed three times for $5 \mathrm{~min}$ using a wash buffer solution and then incubated with exosome specific primary antibody (CD63) at room temperature (RT) for $1 \mathrm{~h}$ on a shaker. Plates were washed and incubated with secondary antibody (1:5000) at RT $1 \mathrm{~h}$ on a shaker. Plates were washed and incubated with Super-sensitive TMB ELISA substrate at RT for $45 \mathrm{~min}$ while shaking. The reaction was terminated using
Stop Buffer solution. Absorbance was measured at $450 \mathrm{~nm}$. The number of exosomes/ml, (ExoELISA ${ }^{\mathrm{TM}} \mathrm{kit}$ ) was obtained using an exosomal CD63 standard curve calibrated against nanoparticle tracking data (i.e., number of exosomes, NanoSight ${ }^{\mathrm{TM}}$ ). The coefficients of intra- and inter-assay variations were less than $8 \%$.

\section{EFFECT OF EXOSOMES ON VASCULAR SMOOTH MUSCLE CELLS (VSMC) MIGRATION}

VSMC were cultured in 231 media supplemented with $0.2 \%$ FBS-exosome free in 96-well culture plate (Corning Life Science, Tewksbury, MA, USA) according to the manufacturer's instructions for 18-24 h. Firstly, we analyzed the effect of cell proliferation on cell migration assay in our experimental conditions using an anti-proliferative drug Mitomycin C (SIGMA-ALDRICH). Cells were plated $\left(1 \times 10^{5}\right.$ cells per well $)$ onto 24 -well plate, and after $24 \mathrm{~h}$ Mitomycin C (50 and $100 \mathrm{ng} / \mathrm{ml}$ ) was added to the cell for $48 \mathrm{~h}$. Cell proliferation was quantified (time-curve) by measuring the cell confluence using a real time imagining 


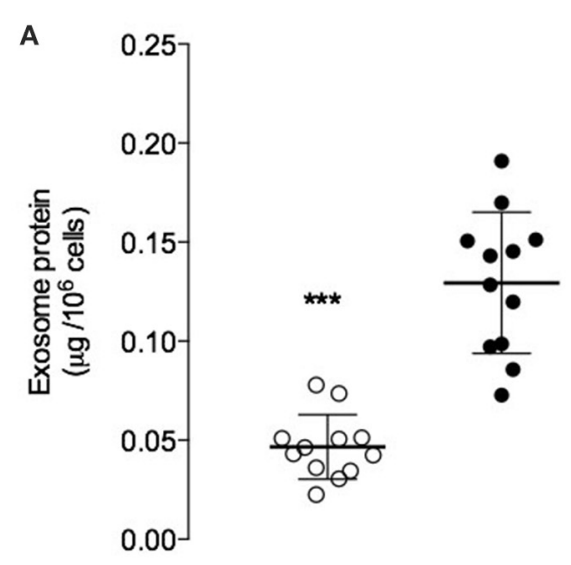

JEG-3 HTR-8/SVneo

B

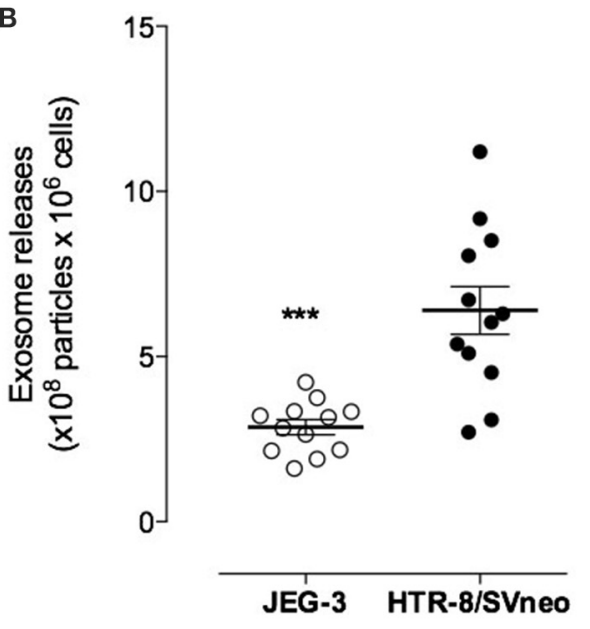

FIGURE 3 | Exosome releases from EVT cell lines. Exosomal protein and number of exosomes were quantified cell conditioned media from JEG-3 and HTR-8/SVneo cells using a colorimetric assay and ELISA kit, respectively. (A) exosomes concentration presented as $\mu \mathrm{g}$ exosomal protein per $10^{6}$ cells and (B) Number of exosomes particles. Data are presented as scatter dot plot and values are mean \pm s.e.m. In (A,B) ${ }^{* * *} p<0.001$ vs. HTR-8/SVneo.

system IncuCyte ${ }^{\mathrm{TM}}$. Simultaneously, VSMC migration assay in the presence of Mitomycin C (50 and $100 \mathrm{ng} / \mathrm{ml})$ for $48 \mathrm{~h}$ was performed.

During experiments, VSMC cells were incubated in the presence (treatment: $100 \mu \mathrm{g}$ exosomal protein/ml) or absence (control) of exosomes for up to $48 \mathrm{~h}$ under $8 \% \mathrm{O}_{2}(n=12)$. The concentration used in this study was based upon exosome doseresponse curves from our previously published studies (Salomon et al., 2013a,b, 2014). Exosomes were subjected to heat inactivation $\left(30 \mathrm{~min}\right.$ at $65^{\circ} \mathrm{C}$ ) or sonication for $30 \mathrm{~min}$ (sonicator bath) before the incubation on VSMC. Cell migration was assessed using a scratch assay format. A scratch was made on confluent monolayers using a 96-pin WoundMaker ${ }^{\mathrm{TM}}$ (BioScience Inc, Ann Arbor, MI, USA). Wound images were automatically acquired and registered by the IncuCyte ${ }^{\mathrm{TM}}$ software system. CellPlayer ${ }^{\mathrm{TM}}$ 96-Well Invasion Assay software was use to fully automate data collection. Data were processed and analyzed using IncuCyte ${ }^{\mathrm{TM}}$ 96-Well Cell Invasion Software Application Module. Data are presented as the Relative Wound Density (RWD, Eizen, v1.0 algorithm). RWD is a representation of the spatial cell density in the wound area relative to the spatial cell density outside of the wound area at every time point (time-curve). Migration assays were performed in the presence of Mitomycin C $(100 \mathrm{ng} / \mathrm{ml})$ to minimize any confounding effects of cell proliferation. The rate of wound closure was compared using the half-maximal stimulatory time $\left(\mathrm{ST}_{50}\right)$ and area under the time course curve (AUC).

\section{EXOSOME INTERNALIZATION}

For exosome uptake analysis, the exosomes pellet (before purification using 30\% sucrose cushion) isolated from JEG-3 and HTR-8/SVneo cells was resuspended in PBS and stained with PKH67 green fluorescent cell linker kit follow the manufacturer's instructions (Sigma-Aldrich). The staining reaction was stopped after $5 \mathrm{~min}$ with exosome-free FBS. Exosomes were then purified using 30\% sucrose cushion as described above. ExosomesPKH67 (100 $\mu \mathrm{g} / \mathrm{ml}$ from JEG-3 and HTR-8/svneo cells) were incubated on VSMC for $24 \mathrm{~h}$ and exosome uptake was quantified using IncuCyte ${ }^{\mathrm{TM}}$ (fluorescent mode). Simultaneously, VSMC were grown in glass bottom chamber slides, and labeled exosomes $(100 \mu \mathrm{g} / \mathrm{ml})$ were added to subconfluent cells. After $24 \mathrm{~h}$, VSMC were washed and fixed using $2 \%$ paraformaldehyde for $5 \mathrm{~min}$ at RT. Cells were immediately analyzed using a Zeiss fluorescence microscope (Axio Imager M1, Zeiss EC Plan-NEOFLUAR $40 \times 10.75$, the Carl Zeiss Group, Germany) with FITC and DAPI absorbance setting.

\section{PROTEOMIC ANALYSIS OF CYTOTROPHOBLAST DERIVED-EXOSOMES BY MASS SPECTROMETRY (MS)}

Isolated exosomes from JEG-3 and HTR-8/SVneo were solubilized in $8 \mathrm{M}$ urea in $50 \mathrm{mM}$ ammonium bicarbonate, $\mathrm{pH} 8.5$, and reduced with DTT for $1 \mathrm{~h}$. Proteins were then alkylated in $10 \mathrm{mM}$ iodoacetic acid (IAA) for $1 \mathrm{~h}$ in the dark. The sample was diluted to $1: 10$ with $50 \mathrm{mM}$ ammonium bicarbonate and digested with trypsin $(20 \mu \mathrm{g})$ at $37^{\circ} \mathrm{C}$ for $18 \mathrm{~h}$. The samples were desalted by solid phase extraction using a STAGE tip protocol (Stop and go extraction tips for matrix-assisted laser desorption/ionization, nano-electrospray, and LC/MS sample pre-treatment in proteomics). The eluted peptides were dried by centrifugal evaporation to remove acetonitrile and redissolved in Solvent A. The resulting peptide mixture was analyzed by liquid chromatography (LC)/mass spectrometry (MS) LC-MS/MS on a 5600 Triple TOF mass spectrometer (AB Sciex, Framingham, USA) equipped with an Eksigent Nanoflow binary gradient HPLC system and a nanospray III ion source. Solvent A was $0.1 \%$ formic acid in water and solvent B was $0.1 \%$ formic acid in acetonitrile. MS/MS spectra were collected using Information Dependent Acquisition (IDA) using a survey scan (m/z 350-1500) followed by 25 data-dependent product ion scans of the 25 most intense precursor ions. All mass spectra were analyzed using the Mascot and Protein Pilot search engines against the Swissprotdatabase with the species set as human. Positive identifications were ascribed where Mascot scores were greater than 30. False discovery rate (FDR) was estimated using a reversed sequence 
A

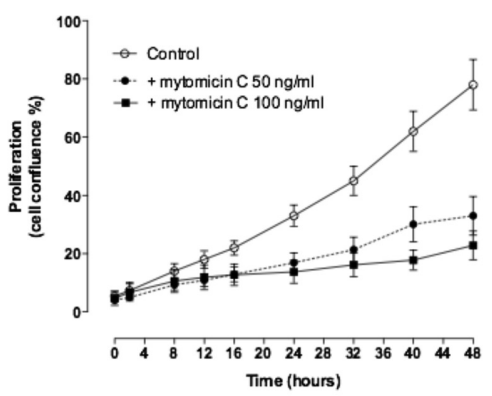

C

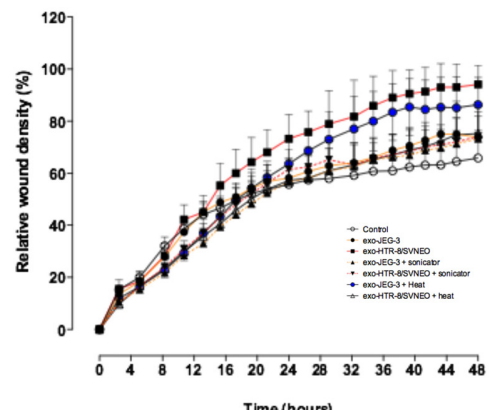

E

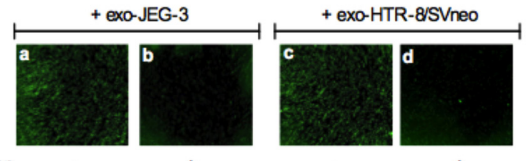

Sonication

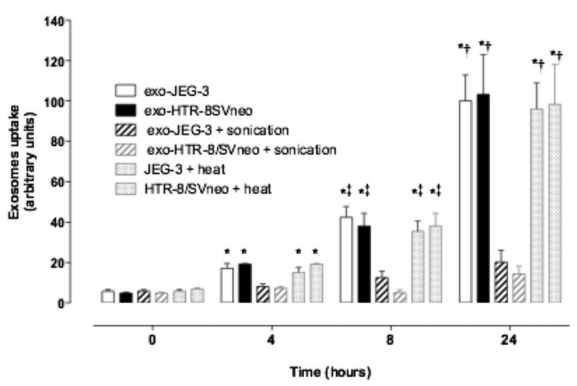

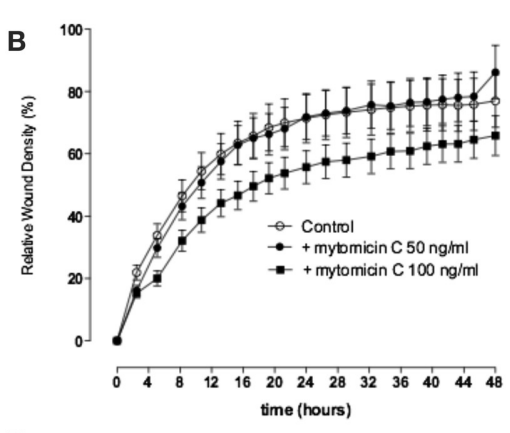

D

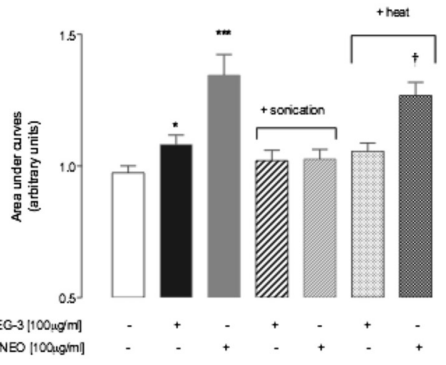

$\mathbf{F}$
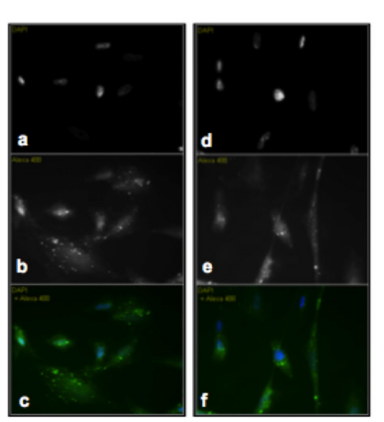

FIGURE 4 | EVT-derived exosomes effects on hVSMC migration. hVSMC were grown to confluence in 231 media and a wound was made using 96 well WoundMaker (see Materials and Methods). hVSMC Migration was measured in absence or presence of $100 \mathrm{ug} / \mathrm{ml}$ of exosomes from JEG-3 and HTR-8/SVneo cells and mitomycin C $(100 \mathrm{ng} / \mathrm{ml})$ for $48 \mathrm{~h}$. Exosome particles were subjected to sonication (+sonication) or heat inactivation (+heat) before exposure to hVSMC cells $(\mathbf{A}, \mathbf{B})$ hVSMC proliferation and migration in the presence of Mitomycin $C$, respectively. (C) Time course of wound closure for hVSMC expressed as relative wound density (\%).
(D) Area under curves from data in (C). (E) Time-dependent uptake of exosomes using a real time imaging system analysis. Top: images after $24 \mathrm{~h}$; Bottom: Graphical representation of exosome uptake. (F) Fluorescent microscopy analysis of exosome uptake (40X). Data represent an $n=12$ well each point with 3 different cells culture. Values are mean \pm SD. In (D) ${ }^{* * *} p<0.001$ vs. all condition except exo-HTR-8/SVneo + heat; and ${ }^{\dagger} p<0.05$ vs. control. In (E) ${ }^{*} p<0.001$ vs. corresponding values at $0 \mathrm{~h}$; ${ }^{\ddagger} p<0.05$ vs. corresponding values control at $4 \mathrm{~h} ;{ }^{\dagger} p<0.05$ vs. corresponding values control at 8 and $4 \mathrm{~h}$. database. Finally, proteins identified were submitted to bioinformatic pathway analysis (Ingenuity Pathway Analysis [IPA]; Ingenuity Systems, Mountain View, CA; www.ingenuity.com).

\section{STATISTICAL ANALYSIS}

Data are represented as mean \pm s.e.m. Comparisons between two group means were performed by unpaired Student's $t$-tests. Multiple groups were compared using the analysis of variance (ANOVA). Post-hoc analyses were used for pairwise comparisons
(Bonferroni correction test). Statistical significance was defined as at least $p<0.05$. Statistical analyses were preformed using commercially available packages (Stata 11, StatCorp, College Station, TX, USA and Prism 6, GraphPad Inc, La Jolla, CA 92037 USA).

\section{RESULTS}

\section{CHARACTERIZATION OF EVT CELL LINES}

Figure 1A presents photomicrographs of wound closure over $40 \mathrm{~h}$ incubation for both cell lines and the percent change in relative 
wound density over time. The migration rate of HTR-8/SVneo was significantly greater than that observed for JEG-3 cells. Half-maximal stimulatory time $\left(\mathrm{ST}_{50}\right)$ was $31.29 \pm 0.14 \mathrm{~h}$ and $15.26 \pm 0.15 \mathrm{~h}$ for JEG-3 and HTR-8SV/neo, respectively $(p<$ 0.05 , Figure 1A, bottom). Area under curves analysis showed that the migration of HTR-8SV/neo was $\sim 2$. 0 -fold greater than that obtained for JEG-3 cells (Figure 1B).

\section{CHARACTERIZATION OF EVT CELL LINE-DERIVED EXOSOMES}

Defining vesicle size range is one of the standard metrics used to confirm that the vesicle preparation in not contaminated with non-exosome vesicles. After differential centrifugation (i.e., $300 \times$ $\mathrm{g}, 2000 \times \mathrm{g}$, and $12,000 \times \mathrm{g}$ ), the supernatant was analyzed using a nanoparticles tracking analysis (NTA). Particle size distribution ranged from 30 to $500 \mathrm{~nm}$, with an average of $180 \pm 100 \mathrm{~nm}$ (Figure 2A). Supernatant was filtered and ultracentrifuged to obtain a particulate fraction (including exosomes particles) with a particle size ranged of 30-200 nm (with a mean diameter of $119 \pm 65 \mathrm{~nm}$, Figure 2B). The exosomes were purified by ultracentrifugation over a sucrose cushion and analyzed using a NTA. The exosome fractions displayed a particle size ranged from 30 to $150 \mathrm{~nm}$ in diameter (with mean of $79 \pm 68 \mathrm{~nm}$, Figure 2C). The presence of exosomal marker CD63 in exosomes isolated from both cell lines was confirmed by Western blot (Figure 2D, top). Finally, exosomes isolated from JEG-3 and HTR-8/SVneo were visualized by transmission electron microscopy (Figure 2D, bottom). Exosomes were identified as small vesicles between 40 and $100 \mathrm{~nm}$. No significant differences in NTA data, CD63 expression and electron microscopy were identified between cell lines.

\section{EXOSOME RELEASE FROM EVT CELL LINES}

Exosomal protein release was expressed as total exosomal protein (i.e., particulate material with a buoyant density of $1.127 \mathrm{~g} / \mathrm{ml}$ ) per million cells $/ 24 \mathrm{~h}$. JEG-3 cells released $46 \pm 16 \mathrm{ng}$ exosomal protein per million cells per $24 \mathrm{~h}(n=4$; i.e., 4 different isolations from $\sim 200 \times 10^{6}$ cells each) whereas HTR-8/SVneo cells released $120 \pm 35 \mathrm{ng}$ exosomal protein per million cells per $24 \mathrm{~h}$ ( $n=4$, Figure 3A). HTR-8/SVneo cells released significantly more exosomes ( $\sim 2.6$-folds $)$ in $24 \mathrm{~h}$ compared to JEG-3 cells $(p<0.0001)$. These results were confirmed by quantifying immunoreactive exosomal CD63. The number of exosomes (NEP) released from HTR-8/SVneo cells $\left(6.39 \times 10^{8} \pm 2.5 \times\right.$ $\left.10^{8} / 24 \mathrm{~h}\right)$ was $\sim 2.3$-fold greater $(p<0.0001)$ than that observed for JEG-3 cells $\left(2.86 \times 10^{8} \pm 0.78 \times 10^{8} / 24 \mathrm{~h}\right.$, Figure 3B $)$.

\section{EFFECT OF EVT-DERIVED EXOSOMES ON CELL MIGRATION}

A VSMC was used to establish the effects of EVT-derived exosomes on cell migration. An anti-proliferative drug Mitomycin $\mathrm{C}(50$ and $100 \mathrm{ng} / \mathrm{ml})$ reduces significantly $(p<0.01)$ VSMC proliferation (Figure 4A). A dose of $100 \mathrm{ng} / \mathrm{ml}$ decreased VSMC migration compared to $50 \mathrm{ng} / \mathrm{ml}$ of Mitomycin $\mathrm{C}$ and control (Figure 4B). The effects of exosomes $(100 \mu \mathrm{g}$ protein $/ \mathrm{ml})$ isolated from JEG-3 and HTR-8/SVneo cultured under $8 \% \mathrm{O}_{2}$ on VSMC migration under $8 \% \mathrm{O}_{2}$ are presented in Figures 4C,D. All experiments were done in the presence of Mitomycin C $(100 \mathrm{ng} / \mathrm{ml})$. The rate of wound closure was significantly increased in the presence of HTR-8/SVneo-derived exosome compared to control (-exosomes) as measured by $\mathrm{ST}_{50}(15.57 \pm 0.32$ vs. $25.09 \pm$ $0.58, p<0.01$ ) (Table 1). Area under curves analysis showed that HTR-8/SVneo-derived exosome increased $\sim 35 \pm 0.2 \%$ VSMC migration compared to control. Similarly, exosomes from JEG-3 cells increased VSMC migration $\sim 12 \pm 0.1 \%$ compared to values in the absence of exosomes (control), however, the effect was smaller compared to exosomes from HTR-8/SVneo. Exosomes were exposed to heat inactivation before incubation on VSMC; however, heat inactivation did not affect the effect of exosomes on VSMC migration. In contrast, sonication completely abolished the HTR-8/SVneo and JEG-3-derived exosomes effect on VSMC migration.

The internalization of exosomes labeled with PKH67 (green) in VSMC was quantified and visualized using The IncuCyte and a fluorescence microscope, respectively (Figures 4E,F). Exosome uptake by VSMC was observed in a time-dependent manner with the maximum at $24 \mathrm{~h}$ (Figure $4 \mathrm{E}$, top panel a and c). Sonication abolished the uptake of fluorescent exosomes (Figure 4E, top panel b and d) compared to exosomes without sonication. Exosome uptake is presented as fluorescent per cell confluence normalized to maximum uptake of $100 \%$. Heat inactivation did not affect the exosomes uptake by VSMC (Figure 4, lower panel). Finally, fluorescence microscope analysis showed an intracellular fluorescent in VSMC cells exposed to intact vesicles from JEG-3 and HTR-8/SVneo (Figure 4F).

\section{PROTEOMIC ANALYSIS OF EVT-DERIVED EXOSOME}

Mass spectrometry analysis identified over 140 exosomal proteins, including cell-line specific exosomal proteins (Table 2 and Figure 5A). Exosomal proteins isolated from JEG-3 and HTR8/SVneo cells were associated with cellular movement and morphology, immune cell trafficking and cellular assembly and organization in accordance with Ingenuity Pathway Analysis (IPA) analysis. The canonical pathways associated with our exosomal proteins isolated from JEG-3 and HTR-8/SVneo cells and defined by IPA Core comparison analysis showed that the score $(-\log [p-$ value]) for proteins associated with cell movement and migration was significantly higher $(\sim 1.2$-fold, $p<0.05)$ in HTR-8/SVneoderived exosomes to compare to exosomes from JEG-3 cells (Figure 5B).

\section{Table 1 | Kinetic characteristic of exosome effects on hVSMC} migration.

\begin{tabular}{lc}
\hline Condition & $\mathbf{S T}_{\mathbf{5 0}}$ (hours) \\
\hline Control & $25.09 \pm 0.58$ \\
+exo-JEG-3 & $21.83 \pm 0.49^{\ddagger}$ \\
+exo-HTR-8/SVneo & $15.57 \pm 0.32^{*}$ \\
+exo-JEG-3 + sonication & $25.06 \pm 0.46$ \\
+exo-HTR-8/SVneo + sonication & $23.27 \pm 0.48$ \\
+exo-JEG-3 + heat & $24.14 \pm 0.35$ \\
+exo-HTR-8/SVneo + heat & $19.43 \pm 0.34^{\dagger}$
\end{tabular}

The effect of exosomes isolated from JEG-3 and HTR-8/SVneo-conditioned media on hVSMC in vitro migration. Data are expressed as half-maximal Stimulatory Time (ST50 in hours) and represent the mean $\pm S D$. ${ }^{*} p<0.05$ vs. control; ${ }^{\dagger} p<0.005$ vs. control and +exo-HTR-8/SVneo. ${ }^{\ddagger} p<0.005$ vs. control. 
Table 2 | List of proteins identified in exosomes isolated from JEG-3 and HTR-8/SVneo cells.

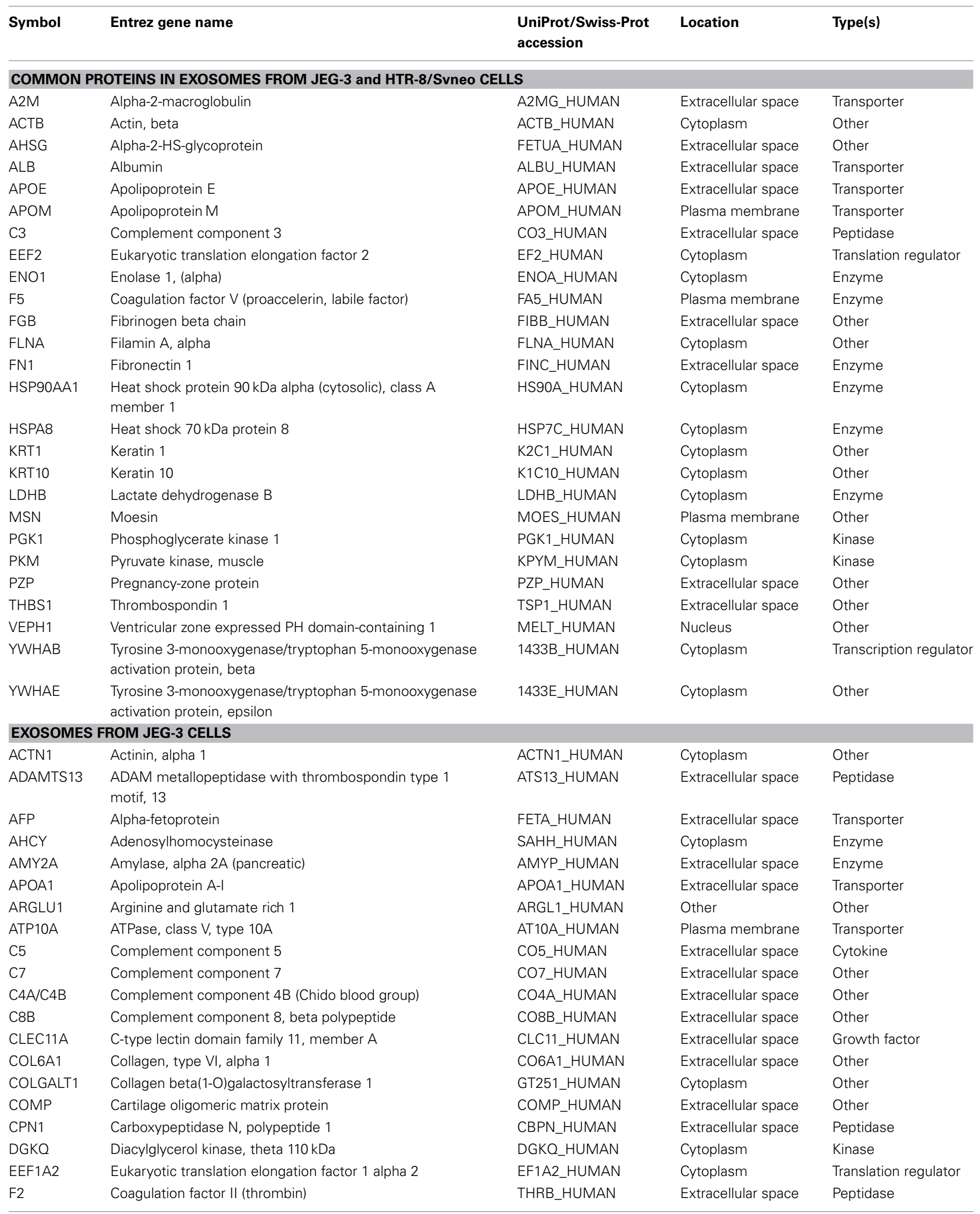


Table 2 | Continued

\begin{tabular}{|c|c|c|c|c|}
\hline Symbol & Entrez gene name & $\begin{array}{l}\text { UniProt/Swiss-Prot } \\
\text { accession }\end{array}$ & Location & Type(s) \\
\hline F10 & Coagulation factor $X$ & FA10_HUMAN & Extracellular space & Peptidase \\
\hline FBLN1 & Fibulin 1 & FBLN1_HUMAN & Extracellular space & Other \\
\hline FGG & Fibrinogen gamma chain & FIBG_HUMAN & Extracellular space & Other \\
\hline GC & Group-specific component (vitamin D binding protein) & VTDB_HUMAN & Extracellular space & Transporter \\
\hline H2AFV & $\mathrm{H} 2 \mathrm{~A}$ histone family, member $\mathrm{V}$ & H2AV_HUMAN & Nucleus & Other \\
\hline $\mathrm{HBB}$ & Hemoglobin, beta & HBB_HUMAN & Cytoplasm & Transporter \\
\hline HIST1H1T & Histone cluster 1, H1t & H1T_HUMAN & Nucleus & Other \\
\hline HIST1H2BB & Histone cluster 1, H2bb & H2B1B_HUMAN & Nucleus & Other \\
\hline HSPA1L & Heat shock 70kDa protein 1-like & HS71L_HUMAN & Other & Other \\
\hline LINC00083 & Long intergenic non-protein coding RNA 83 & YA021_HUMAN & Other & Other \\
\hline LRP1 & Low density lipoprotein receptor-related protein 1 & LRP1_HUMAN & Plasma membrane & $\begin{array}{l}\text { Transmembrane } \\
\text { receptor }\end{array}$ \\
\hline LUM & Lumican & LUM_HUMAN & Extracellular space & Other \\
\hline MYH9 & Myosin, heavy chain 9 , non-muscle & MYH9_HUMAN & Cytoplasm & Transporter \\
\hline MYL6 & Myosin, light chain 6, alkali, smooth muscle and non-muscle & MYL6_HUMAN & Cytoplasm & Other \\
\hline NHSL2 & NHS-like 2 & NHSL2_HUMAN & Other & Other \\
\hline OR2W3 & Olfactory receptor, family 2 , subfamily W, member 3 & OR2W3_HUMAN & Plasma membrane & $\begin{array}{l}\text { G-protein coupled } \\
\text { receptor }\end{array}$ \\
\hline PIF1 & PIF1 5'-to-3' DNA helicase & PIF1_HUMAN & Nucleus & Enzyme \\
\hline PITRM1 & Pitrilysin metallopeptidase 1 & PREP_HUMAN & Cytoplasm & Peptidase \\
\hline SERPINF2 & $\begin{array}{l}\text { Serpin peptidase inhibitor, clade } \mathrm{F} \text { (alpha- } 2 \text { antiplasmin, } \\
\text { pigment epithelium derived factor), member } 2\end{array}$ & A2AP_HUMAN & Extracellular space & Other \\
\hline THBS4 & Thrombospondin 4 & TSP4_HUMAN & Extracellular space & Other \\
\hline TLN1 & Talin 1 & TLN1_HUMAN & Plasma membrane & Other \\
\hline TUBA1B & Tubulin, alpha $1 \mathrm{~b}$ & TBA1B_HUMAN & Cytoplasm & Other \\
\hline TUBA4A & Tubulin, alpha $4 a$ & TBA4A_HUMAN & Cytoplasm & Other \\
\hline VTN & Vitronectin & VTNC_HUMAN & Extracellular space & Other \\
\hline YWHAZ & $\begin{array}{l}\text { Tyrosine 3-monooxygenase/tryptophan 5-monooxygenase } \\
\text { activation protein, zeta }\end{array}$ & 1433Z_HUMAN & Cytoplasm & Enzyme \\
\hline ZNF480 & Zinc finger protein 480 & ZN480_HUMAN & Nucleus & Other \\
\hline \multicolumn{5}{|c|}{ EXOSOMES FROM HTR-8/SVneo CELLS } \\
\hline AASDH & Aminoadipate-semialdehyde dehydrogenase & ACSF4_HUMAN & Other & Enzyme \\
\hline ACTN4 & Actinin, alpha 4 & ACTN4_HUMAN & Cytoplasm & Other \\
\hline ALDOA & Aldolase A, fructose-bisphosphate & ALDOA_HUMAN & Cytoplasm & Enzyme \\
\hline ANXA2 & Annexin A2 & ANXA2_HUMAN & Plasma membrane & Other \\
\hline ANXA5 & Annexin A5 & ANXA5_HUMAN & Plasma membrane & Other \\
\hline ANXA6 & Annexin A6 & ANXA6_HUMAN & Plasma membrane & Other \\
\hline APOB & Apolipoprotein B & APOB_HUMAN & Extracellular space & Transporter \\
\hline
\end{tabular}


Table 2 | Continued

\begin{tabular}{|c|c|c|c|c|}
\hline Symbol & Entrez gene name & $\begin{array}{l}\text { UniProt/Swiss-Prot } \\
\text { accession }\end{array}$ & Location & Type(s) \\
\hline ARAP2 & $\begin{array}{l}\text { ArfGAP with RhoGAP domain, ankyrin repeat and PH } \\
\text { domain } 2\end{array}$ & ARAP2_HUMAN & Cytoplasm & Other \\
\hline ART4 & ADP-ribosyltransferase 4 (Dombrock blood group) & NAR4_HUMAN & Nucleus & Enzyme \\
\hline ATP1A1 & ATPase, $\mathrm{Na}^{+} / \mathrm{K}^{+}$transporting, alpha 1 polypeptide & AT1A1_HUMAN & Plasma membrane & Transporter \\
\hline B2M & Beta-2-microglobulin & B2MG_HUMAN & Plasma membrane & $\begin{array}{l}\text { Transmembrane } \\
\text { receptor }\end{array}$ \\
\hline BASP1 & Brain abundant, membrane attached signal protein 1 & BASP1_HUMAN & Nucleus & Transcription regulator \\
\hline BMS1 & BMS1 ribosome biogenesis factor & BMS1_HUMAN & Nucleus & Other \\
\hline C9 & Complement component 9 & CO9_HUMAN & Extracellular space & Other \\
\hline C7orf61 & Chromosome 7 open reading frame 61 & CG061_HUMAN & Other & Other \\
\hline CD59 & CD59 molecule, complement regulatory protein & CD59_HUMAN & Plasma membrane & Other \\
\hline $\mathrm{CHM}$ & Choroideremia (Rab escort protein 1) & RAE1_HUMAN & Cytoplasm & Enzyme \\
\hline FSCN1 & $\begin{array}{l}\text { Fascin homolog 1, actin-bundling protein } \\
\text { (Strongylocentrotus purpuratus) }\end{array}$ & FSCN1_HUMAN & Cytoplasm & Other \\
\hline GAPDH & Glyceraldehyde-3-phosphate dehydrogenase & G3P_HUMAN & Cytoplasm & Enzyme \\
\hline GLP2R & Glucagon-like peptide 2 receptor & GLP2R_HUMAN & Plasma membrane & $\begin{array}{l}\text { G-protein coupled } \\
\text { receptor }\end{array}$ \\
\hline GNAI2 & $\begin{array}{l}\text { Guanine nucleotide binding protein (G protein), alpha } \\
\text { inhibiting activity polypeptide } 2\end{array}$ & GNAI2_HUMAN & Plasma membrane & Enzyme \\
\hline GNB1 & $\begin{array}{l}\text { Guanine nucleotide binding protein (G protein), beta } \\
\text { polypeptide } 1\end{array}$ & GBB1_HUMAN & Plasma membrane & Enzyme \\
\hline GNG12 & Guanine nucleotide binding protein (G protein), gamma 12 & GBG12_HUMAN & Plasma membrane & Enzyme \\
\hline $\mathrm{HBD}$ & Hemoglobin, delta & HBD_HUMAN & Other & Transporter \\
\hline ITGA3 & $\begin{array}{l}\text { integrin, alpha } 3 \text { (antigen CD } 49 C \text {, alpha } 3 \text { subunit of VLA-3 } \\
\text { receptor) }\end{array}$ & ITA3_HUMAN & Plasma membrane & Other \\
\hline ITGB1 & $\begin{array}{l}\text { Integrin, beta } 1 \text { (fibronectin receptor, beta polypeptide, } \\
\text { antigen CD29 includes MDF2, MSK12) }\end{array}$ & ITB1_HUMAN & Plasma membrane & $\begin{array}{l}\text { Transmembrane } \\
\text { receptor }\end{array}$ \\
\hline KRT9 & Keratin 9 & K1C9_HUMAN & Cytoplasm & Other \\
\hline LGALS1 & Lectin, galactoside-binding, soluble, 1 & LEG1_HUMAN & Extracellular space & Other \\
\hline MFGE8 & Milk fat globule-EGF factor 8 protein & MFGM_HUMAN & Extracellular space & Other \\
\hline MIF & $\begin{array}{l}\text { Macrophage migration inhibitory factor } \\
\text { (glycosylation-inhibiting factor) }\end{array}$ & MIF_HUMAN & Extracellular space & Cytokine \\
\hline NCL & Nucleolin & NUCL_HUMAN & Nucleus & Other \\
\hline NME2 & NME/NM23 nucleoside diphosphate kinase 2 & NDKB_HUMAN & Nucleus & Kinase \\
\hline NRG1 & Neuregulin 1 & NRG1_HUMAN & Other & Growth factor \\
\hline PARK7 & Parkinson protein 7 & PARK7_HUMAN & Nucleus & Enzyme \\
\hline PGAM1 & Phosphoglycerate mutase 1 (brain) & PGAM1_HUMAN & Cytoplasm & Phosphatase \\
\hline PRDX1 & Peroxiredoxin 1 & PRDX1_HUMAN & Cytoplasm & Enzyme \\
\hline PTGFRN & Prostaglandin F2 receptor inhibitor & FPRP_HUMAN & Plasma membrane & Other \\
\hline RUVBL2 & RuvB-like AAA ATPase 2 & RUVB2_HUMAN & Nucleus & transcription regulator \\
\hline S100A11 & S100 calcium binding protein A11 & S10AB_HUMAN & Cytoplasm & Other \\
\hline SERPINA1 & $\begin{array}{l}\text { Serpin peptidase inhibitor, clade A (alpha-1 antiproteinase, } \\
\text { antitrypsin), member } 1\end{array}$ & A1AT_HUMAN & Extracellular space & Other \\
\hline
\end{tabular}


Table 2 | Continued

\begin{tabular}{|c|c|c|c|c|}
\hline Symbol & Entrez gene name & $\begin{array}{l}\text { UniProt/Swiss-Prot } \\
\text { accession }\end{array}$ & Location & Type(s) \\
\hline SLC16A3 & $\begin{array}{l}\text { Solute carrier family } 16 \text { (monocarboxylate transporter), } \\
\text { member } 3\end{array}$ & MOT4_HUMAN & Plasma membrane & Transporter \\
\hline SLC2A1 & $\begin{array}{l}\text { Solute carrier family } 2 \text { (facilitated glucose transporter), } \\
\text { member } 1\end{array}$ & GTR1_HUMAN & Plasma membrane & Transporter \\
\hline STARD13 & StAR-related lipid transfer (START) domain containing 13 & STA13_HUMAN & Cytoplasm & Other \\
\hline TMEM262 & Transmembrane protein 262 & YK025_HUMAN & Other & Other \\
\hline TPI1 & Triosephosphate isomerase 1 & TPIS_HUMAN & Cytoplasm & Enzyme \\
\hline TRRAP & Transformation/transcription domain-associated protein & TRRAP_HUMAN & Nucleus & Transcription regulator \\
\hline TUBBP5 & Tubulin, beta pseudogene 5 & YI016_HUMAN & Other & Other \\
\hline UBAC2 & UBA domain containing 2 & UBAC2_HUMAN & Cytoplasm & Enzyme \\
\hline VIM & Vimentin & VIME_HUMAN & Cytoplasm & Other \\
\hline
\end{tabular}

All mass spectra were analyzed using the Mascot and Protein Pilot search engines against the Swissprot-swissprot database with the species set as human (score

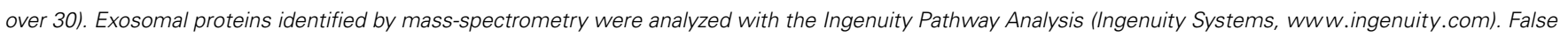

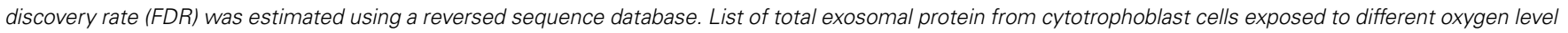
are presented as Protein ID, Symbol, Entrez Gene Name, Location, and type.
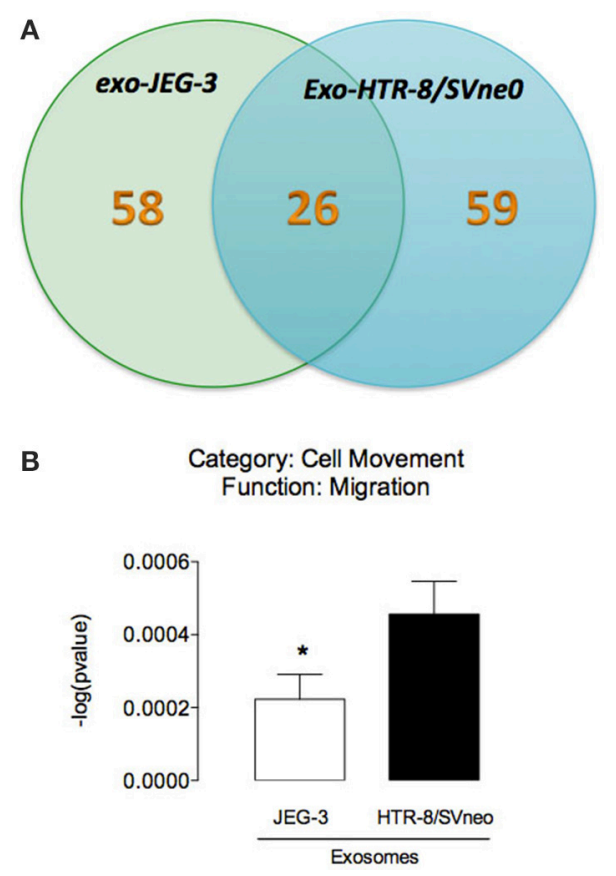

FIGURE 5 | Analysis of EVT cell-derived exosomes proteins. (A) The Venn diagram represents the distribution of common and unique proteins identified by nanospray LC-MS/MS (ABSciex 5600) in exosomes released from JEG-3 and HTR-8/SVneo cells. (B) Comparison of biological function (cell movement and migration) identified by IPA core analysis. In (B) values are mean \pm s.e.m. In (B) $* p<0.05$ vs. HTR-8/SVneo cells.

\section{DISCUSSION}

A tenet of contemporary obstetrics is that events that compromise placentation and the development of the materno-fetal exchange increase the risk of complications of pregnancy and contribute to poor pregnancy outcome. In particular, conditions that affect the differentiation and invasion of placental cells compromise placental perfusion and function (Jauniaux et al., 2006, 2010; Burton et al., 2009) and the subsequent growth and development of the fetus (Khong et al., 1987). EVT migrate into maternal decidua and myometrium and interact with VSMC in uterine spiral arteries. Conversion of these arteries is associated with the loss of VSMC from the vessel wall by migration out of the vessel. In this study we established that: (1) exosome isolated from EVT-like cell lines (JEG-3 and HTR-8/SVneo) with different cellular origins (choriocarcinoma and EVT) exhibit differences in their rate of release, protein content and bioactivity; and (2) both exosomes from JEG-3 and HTR-8/SVneo cells increase VSMC migration. However, the effect of exosomes from HTR-8/SVneo was significantly higher. Exosomes released from first trimester trophoblast cells (EVT), therefore, may regulate processes that play a key role in placentation and remodeling of the uterine spiral arteries.

The interactions between EVT and VSMC are not fully understood, in part due to difficulties of accessing first trimester samples and the lack of suitable animal models (Carter, 2007; Ackerman et al., 2013). We obtained nanovesicles with high purity. The data presented establish that the final preparation used display a size distribution and buoyant consistent with exosomes and the lack of significant contamination by microsomes. In this study, we quantified the release of exosomes from JEG-3 and HTR-8/SVneo cells (as indicated by immunoreactive exosomal CD63). The data obtained establish that exosome release is cell type specific and correlated with cell migration capacity. Consistent with these data, a correlation between exosome release and cell invasiveness has been described previously in ovarian cancer cells (Kobayashi et al., 2014).

The initial stages of uterine SpA remodeling involves a loss of the VSMC component by apoptosis, migration or a combination of both processes. In this study, we identify a novel exosomal signaling pathway by which EVT (HTR-8/SVneo cells) promote the 
migration of VSMC. Consistent with these data, Bulmer et al. (2012) observed that VSMC migration plays a major role in remodeling of the artery by migration into the decidua and vessel lumen and this phenomenon is enhanced in the presence of EVT cells (Bulmer et al., 2012). Based upon the available data, we propose that perivascular EVT release exosomes that interaction with VSMC and promote their migration out of SpAs and alter the vasoreactive of these vessels. This effect of exosomes on VSMC migration was cell-type specific (i.e., only exosomes from HTR-8/SVneo cells promote cell migration) and may reflect the different cellular origin of the two cell lines compared in this study. HTR-8/SVneo cells are derived by transfection of first trimester trophoblast cells (Graham et al., 1993). JEG-3 cells are derived from a choriocarcinoma (Kohler and Bridson, 1971). Difference in the molecular cargo carried by exosomes released from HTR-8/SVneo and JEG-3 cell may account for their different effects on target cell migration. Consistent with this suggestion, proteins involved in cell migration were differentially represented in exosomes isolated from the two-cell lines.

The exosomal content is highly dependent on the cell origin and on pre-conditioning of the cell. Exosomes function as a carrier of specific molecules such as, proteins, lipids, mRNA, and miRNA and can interact with neighboring cells or travel long distances in the bloodstream to reprogram the phenotype and regulate their function (Denzer et al., 2000). In this study, we identified unique proteins (58 and 59 proteins in exosome from JEG-3 and HTR-8/SVneo cells) and common proteins (26) between these EVT cell lines. Ingenuity Pathway Analysis (IPA) of exosomal proteins identified cell-dependent changes in cell movement and migration signaling pathways. Exosomes have been reported to express a diverse range of cell surface receptors, proteins (including, heat shock proteins, cytoskeletal proteins, adhesion molecules, membrane transport, and fusion proteins), mRNA and miRNA with the potential to affect the acute and long-term function of the cells with which they interact (Ambros, 2004). Recent data demonstrate that trophoblast-derived exosomes induce proinflammatory cytokines such IL-1 $\beta$ in human macrophages cells (Atay et al., 2011). Furthermore, in vitro exposure of PBMC and dendritic cells to exosomal proteins induce differentiation of stem cells; suppression of activation of natural killer cells and macrophages; and stimulation of cell migration (Mincheva-Nilsson et al., 2006; Knight, 2008; Soo et al., 2012). Interestingly, protein analysis revealed that exosome release from cytrophoblast cells increases with low oxygen tension and their exosome promotes cell migration in extravillous cytotrophoblast (HTR-8/SVneo) (Salomon et al., 2013b).

The observed effects of HTR-8/SVneo-derived exosomes on VSCM migration were also dependent upon exosome structural integrity. Disruption of exosomes by sonication (Delorme-Axford et al., 2013) completely abolished their effect on VSMC migration. While the precise mechanisms by which sonication abolishes the effects of exosomes remains to be established, preventing exosomal fusion with VSMC cell membrane and the intracellular delivery of signaling molecules and/or the loss of capacity to appropriately present exosomal surface moieties to target cell receptors represent possible pathways and warrant further investigation. We establish in this study that exosome integrity is critical to mediating their effects on VSMC migration. It is not possible from the data obtained in this study to differentiate between sonication-induced disruption of exosome: uptake; fusion; activation of VSMC cell surface receptors, or a combination of these (and other) mechanisms. The elucidation of contribution of these mechanisms will require additional extensive studies to establish.

In conclusion, using in vitro EVT-like cell lines, we have demonstrated difference in release, composition and bioactivity between exosomes from JEG-3 and HTR-8/SVneo cells. Exosomes released from EVT may play a role in remodeling $\mathrm{SpA}$ by promoting migration of VSMC. Exosomal-induced VSCM migration is associated with increased representation of proteins involved in cell migration processes within their molecular cargo and dependent upon exosomal structural integrity. The identification of this EVT-VSMC exosomal communication pathway not only affords opportunity for developing biomarkers of placentation but also the assessment of exosome targeted therapeutic innervation strategies.

\section{AUTHOR CONTRIBUTIONS}

Carlos Salomon, Sarah Yee, Katherin Scholz-Romero, Kanchan Vaswani, Miharu Kobayashi and David Kvaskoff contributed in generating experimental data. Carlos Salomon, Sebastian E. Illanes, Murray D. Mitchell and Gregory E. Rice contributed in discussion and reviewed/edited manuscript. Carlos Salomon and Gregory E. Rice wrote the manuscript and drew the figures.

\section{ACKNOWLEDGMENTS}

We acknowledge the assistance of Dr. Jamie Riches and Dr. Rachel Hancock of the Central Analytical Research Facility, Institute for Future Environments, Queensland University of Technology (QUT) for the electron microscope analyses.

\section{REFERENCES}

American Diabetes Association. (2012). Diagnosis and classification of diabetes mellitus. Diabetes Care 35(Suppl. 1), S64-S71. doi: 10.2337/dc12-s064

Ackerman, W. E. 4th., Carter, A. M., De Mestre, A. M., Golos, T. G., Jeschke, U., Kusakabe, K., et al. (2013). IFPA Meeting 2012 Workshop Report I: comparative placentation and animal models, advanced techniques in placental histopathology, human pluripotent stem cells as a model for trophoblast differentiation. Placenta 34(Suppl.), S3-S5. doi: 10.1016/j.placenta.2012.11.006

Ambros, V. (2004). The functions of animal microRNAs. Nature 431, 350-355. doi: 10.1038 /nature02871

Atay, S., Gercel-Taylor, C., Suttles, J., Mor, G., and Taylor, D. D. (2011). Trophoblastderived exosomes mediate monocyte recruitment and differentiation. Am. J. Reprod. Immunol. 65, 65-77. doi: 10.1111/j.1600-0897.2010.00880.x

Blackburn, C. A., Keelan, J. A., Taylor, R. S., and North, R. A. (2003). Maternal serum activin $\mathrm{A}$ is not elevated before preeclampsia in women who are at high risk. Am. J. Obstet. Gynecol. 188, 807-811. doi: 10.1067/mob.2003.173

Bulmer, J. N., Innes, B. A., Levey, J., Robson, S. C., and Lash, G. E. (2012). The role of vascular smooth muscle cell apoptosis and migration during uterine spiral artery remodeling in normal human pregnancy. FASEB J. 26, 2975-2985. doi: 10.1096/fj.12-203679

Burton, G. J., Charnock-Jones, D. S., and Jauniaux, E. (2009). Regulation of vascular growth and function in the human placenta. Reproduction 138, 895-902. doi: 10.1530/REP-09-0092

Carter, A. M. (2007). Animal models of human placentation-a review. Placenta 28(Suppl. A), S41-S47. doi: 10.1016/j.placenta.2006.11.002

Chen, G., Zhang, Y., and Wu, X. (2014). 786-0 Renal cancer cell line-derived exosomes promote 786-0 cell migration and invasion. Oncol. Lett. 7, 1576-1580. doi: 10.3892/ol.2014.1962 
Delorme-Axford, E., Donker, R. B., Mouillet, J. F., Chu, T., Bayer, A., Ouyang, Y., et al. (2013). Human placental trophoblasts confer viral resistance to recipient cells. Proc. Natl. Acad. Sci. U.S.A. 110, 12048-12053. doi: 10.1073/pnas. 1304718110

Denzer, K., Kleijmeer, M. J., Heijnen, H. F., Stoorvogel, W., and Geuze, H. J. (2000). Exosome: from internal vesicle of the multivesicular body to intercellular signaling device. J. Cell Sci. 113, 3365-3374.

Graham, C. H., Hawley, T. S., Hawley, R. G., MacDougall, J. R., Kerbel, R. S., Khoo, N., et al. (1993). Establishment and characterization of first trimester human trophoblast cells with extended lifespan. Exp. Cell Res. 206, 204-211. doi: 10.1006/excr.1993.1139

Hamilton, W. J., and Boyd, J. D. (1970). The Human Placenta. Cambridge: W. Heffer \& Sons.

Jauniaux, E., Poston, L., and Burton, G. J. (2006). Placental-related diseases of pregnancy: involvement of oxidative stress and implications in human evolution. Hum. Reprod. Update 12, 747-755. doi: 10.1093/humupd/dml016

Jauniaux, E., Van Oppenraaij, R. H. F., and Burton, G. J. (2010). Obstetric outcome after early placental complications. Curr. Opin. Obstetr. Gynecol. 22, 452-457. doi: 10.1097/GCO.0b013e3283404e44

Kam, E. P., Gardner, L., Loke, Y. W., and King, A. (1999). The regulation of trophoblast differentiation by oxygen in the physiological change in decidual spiral arteries. Hum. Reprod. 14, 2131-2138. doi: 10.1093/humrep/14.8.2131

Khong, T. Y., Liddell, H. S., and Robertson, W. B. (1987). Defective hemochorial placentation as a cause of miscarriage - a preliminary-study. Br. J. Obstetr. Gynaecol. 94, 649-655. doi: 10.1111/j.1471-0528.1987.tb03169.x

Knight, A. M. (2008). Regulated release of B cell-derived exosomes: do differences in exosome release provide insight into different APC function for B cells and DC? Eur. J. Immunol. 38, 1186-1189. doi: 10.1002/eji.200838374

Kobayashi, M., Salomon, C., Tapia, J., Illanes, S. E., Mitchell, M. D., and Rice, G. E. (2014). Ovarian cancer cell invasiveness is associated with discordant exosomal sequestration of Let-7 miRNA and miR-200. J. Transl. Med. 12, 4. doi: 10.1186/1479-5876-12-4

Kohler, P. O., and Bridson, W. E. (1971). Isolation of hormone-producing clonal lines of human choriocarcinoma. J. Clin. Endocrinol. Metab. 32, 683-687. doi: 10.1210/jcem-32-5-683

Lee, H. D., Kim, Y. H., and Kim, D. S. (2014). Exosomes derived from human macrophages suppress endothelial cell migration by controlling integrin trafficking. Eur. J. Immunol. 44, 1156-1169. doi: 10.1002/eji.201343660

Mincheva-Nilsson, L., Nagaeva, O., Chen, T., Stendahl, U., Antsiferova, J., Mogren, I., et al. (2006). Placenta-derived soluble MHC class I chain-related molecules down-regulate NKG2D receptor on peripheral blood mononuclear cells during human pregnancy: a possible novel immune escape mechanism for fetal survival. J. Immunol. 176, 3585-3592. doi: 10.4049/jimmunol.176. 6.3585

Morales-Prieto, D. M., Chaiwangyen, W., Ospina-Prieto, S., Schneider, U., Herrmann, J., Gruhn, B., et al. (2012). MicroRNA expression profiles of trophoblastic cells. Placenta 33, 725-734. doi: 10.1016/j.placenta.2012.05.009

Pegtel, D. M., Cosmopoulos, K., Thorley-Lawson, D. A., van Eijndhoven, M. A. J., Hopmans, E. S., Lindenberg, J. L., et al. (2010). Functional delivery of viral miRNAs via exosomes. Proc. Natl. Acad. Sci. U.S.A. 107, 6328-6333. doi: 10.1073/pnas.0914843107

Pijnenborg, R., Ball, E., Bulmer, J. N., Hanssens, M., Robson, S. C., and Vercruysse, L. (2006a). In vivo analysis of trophoblast cell invasion in the human. Methods Mol. Med. 122, 11-44. doi: 10.1385/1-59259-989-3:9

Pijnenborg, R., Vercruysse, L., and Hanssens, M. (2006b). The uterine spiral arteries in human pregnancy: facts and controversies. Placenta 27, 939-958. doi: 10.1016/j.placenta.2005.12.006
Pijnenborg, R., Bland, J. M., Robertson, W. B., and Brosens, I. (1983). Uteroplacental arterial changes related to interstitial trophoblast migration in early human pregnancy. Placenta 4, 397-413. doi: 10.1016/S01434004(83)80043-5

Salomon, C., Ryan, J., Sobrevia, L., Kobayashi, M., Ashman, K., Mitchell, M., et al. (2013a). Exosomal signaling during hypoxia mediates microvascular endothelial cell migration and vasculogenesis. PLOS ONE 8:e68451. doi: 10.1371/journal.pone.0068451

Salomon, C., Kobayashi, M., Ashman, K., Sobrevia, L., Mitchell, M. D., and Rice, G. E. (2013b). Hypoxia-induced changes in the bioactivity of cytotrophoblastderived exosomes. PLoS ONE 8:e79636. doi: 10.1371/journal.pone.0079636

Salomon, C., Torres, M., Kobayashi, M., Scholz-Romero, K., Sobrevia, L., Dobierzewska, A., et al. (2014). A gestational profile of placental exosomes in maternal plasma and their effects on endothelial cell migration. PLoS ONE. 9:e98667. doi: 10.1371/journal.pone.0098667

Soo, C. Y., Song, Y., Zheng, Y., Campbell, E. C., Riches, A. C., Gunn-Moore, F., et al. (2012). Nanoparticle tracking analysis monitors microvesicle and exosome secretion from immune cells. Immunology 136, 192-197. doi: 10.1111/j.13652567.2012.03569.x

Suman, P., and Gupta, S. K. (2012). Comparative analysis of the invasionassociated genes expression pattern in first trimester trophoblastic (HTR8/SVneo) and JEG-3 choriocarcinoma cells. Placenta 33, 874-877. doi: 10.1016/j.placenta.2012.06.017

Thery, C. (2011). Exosomes: secreted vesicles and intercellular communications. F1000 Biol. Rep. 3, 15. doi: 10.3410/B3-15

Vlassov, A. V., Magdaleno, S., Setterquist, R., and Conrad, R. (2012). Exosomes: current knowledge of their composition, biological functions, and diagnostic and therapeutic potentials. Bba-Gen. Subjects 1820, 940-948. doi: 10.1016/j.bbagen.2012.03.017

Weber, M., Knoefler, I., Schleussner, E., Markert, U. R., and Fitzgerald, J. S. (2013). HTR8/SVneo cells display trophoblast progenitor cell-like characteristics indicative of self-renewal, repopulation activity, and expression of stemness- associated transcription factors. BioMed. Res. Int. 2013, 243649. doi: $10.1155 / 2013 / 243649$

Yoon, J. H., Kim, J., Kim, K. L., Kim, D. H., Jung, S. J., Lee, H., et al. (2014). Proteomic analysis of hypoxia-induced U373MG glioma secretome reveals novel hypoxia-dependent migration factors. Proteomics 14, 1494-1502. doi: 10.1002/pmic. 201300554

Conflict of Interest Statement: The authors declare that the research was conducted in the absence of any commercial or financial relationships that could be construed as a potential conflict of interest.

Received: 01 May 2014; accepted: 07 July 2014; published online: 11 August 2014. Citation: Salomon C, Yee S, Scholz-Romero K, Kobayashi M, Vaswani K, Kvaskoff D, Illanes SE, Mitchell MD and Rice GE (2014) Extravillous trophoblast cells-derived exosomes promote vascular smooth muscle cell migration. Front. Pharmacol. 5:175. doi: 10.3389/fphar.2014.00175

This article was submitted to Cardiovascular and Smooth Muscle Pharmacology, a section of the journal Frontiers in Pharmacology.

Copyright (C) 2014 Salomon, Yee, Scholz-Romero, Kobayashi, Vaswani, Kvaskoff, Illanes, Mitchell and Rice. This is an open-access article distributed under the terms of the Creative Commons Attribution License (CC BY). The use, distribution or reproduction in other forums is permitted, provided the original author(s) or licensor are credited and that the original publication in this journal is cited, in accordance with accepted academic practice. No use, distribution or reproduction is permitted which does not comply with these terms. 